\title{
Initial Growth and Roots Development of Soybean as Function of Water Availability and Soil Bulk Density
}

\author{
Pâmela de Andrades Timm ${ }^{1}$, Marília Alves Brito Pinto ${ }^{2}$, José Maria Barbat Parfitt ${ }^{3}$, Germani Concenço ${ }^{3}$, \\ Alexssandra Dayanne Soares de Campos ${ }^{1}$, Thayse do Amaral Aires ${ }^{1}$, Jaqueline Trombetta da Silva ${ }^{4}$ \\ $\&$ Lessandro Coll Faria ${ }^{2}$ \\ ${ }^{1}$ School of Agronomy, Federal University of Pelotas, Capão do Leão, Brazil \\ ${ }^{2}$ School of Water Resources Engineering, Federal University of Pelotas, Pelotas, Brazil \\ ${ }^{3}$ Brazilian Agricultural Research Corporation, Embrapa Temperate Agriculture, Pelotas, Brazil \\ ${ }^{4}$ Soil and Water Conservation and Management Post-graduate Program, Federal University of Pelotas, Capão do \\ Leão, Brazil \\ Correspondence: Germani Concenço, Brazilian Agricultural Research Corporation, Embrapa Temperate \\ Agriculture, Rodovia BR 392, km 78, Postal Code 96010-971, Pelotas, RS, Brazil. Tel: 55-53-3275-8493. E-mail: \\ germani.concenco@embrapa.br
}

Received: June 8, 2019

Accepted: August 4, $2019 \quad$ Online Published: September 30, 2019

doi:10.5539/jas.v11n16p213

URL: https://doi.org/10.5539/jas.v11n16p213

\begin{abstract}
Soil compaction is preponderant in soil physical-hydric relationships, which in turn, exert direct effect on plant development. In this context, this work aimed to evaluate the initial development of shoot and roots of soybean plants (Glycine $\max (\mathrm{L}$.$) Merril), cv. BMX Ícone, cultivated in different combinations of soil bulk densities and$ water availability. A greenhouse experiment was carried out at the EMBRAPA Lowland Experimental Station, Rio Grande do Sul, Brazil. Soybean plants were grown in seven levels of soil bulk density $(1.4,1.5,1.6,1.7,1.8$, 1.9 and $2.0 \mathrm{~kg} \mathrm{dm}^{-3}$ ) coupled to two soil water tensions (10 and $\left.50 \mathrm{kPa}\right)$. Plant height and leaf area, as well as root volume, decreased when soybean was cultivated at $50 \mathrm{kPa}$, associated to soil bulk densities above $1.8 \mathrm{~kg}$ $\mathrm{dm}^{-3}$. Soybean crop showed to be most sensitive to water deficit than to soil compaction, and soil water tension around the field capacity $(10 \mathrm{kPa})$ should be associated to soil bulk density lower than $1.8 \mathrm{~kg} \mathrm{dm}^{-3}$ to allow adequate soybean crop development.
\end{abstract}

Keywords: leaf area, root system, water deficit, soil compaction

\section{Introduction}

Soil compaction is preponderant in the physical, chemical and biological relationships of the soil, which affect plants growth (Beutler \& Centurion, 2003). As soil bulk density increases, there is a decrease in total porosity and soil resistance to root penetration is augmented, posing an impediment to root growth and restricting water and air movement throughout the soil profile (Chen, Weil, \& Hill, 2014).

Some studies show that soil compaction has a negative effect on soybean yield (Beutler \& Centurion, 2003; Calonego, Raphael, Rigon, Oliveira Neto, \& Rosolem, 2017) and root development (Cardoso et al., 2006; Colombi \& Walter, 2015; Ramos et al., 2018); other studies evaluate the effect of water availability on soybean crop (Fioreze, Pivetta, Fano, Machado, \& Guimarães, 2005; Sartori et al., 2016) establishing the soil moisture threshold levels to achieve high grain yields. However, few studies evaluate soil compaction and its association with the appearance of water deficit symptoms on the development of soybean plants and their root system.

This association is important, since soil compaction reduces average pore size (Watson \& Kelsey, 2006) and in progressively smaller pores the matric potential is lower causing the water to be adsorbed most strongly to solid surfaces. It makes difficult for plants to remove water from soil at rates sufficient to supply their needs (Brady \& Weil, 1999).

Once roots do not capture enough water, the plant should limit water loss through transpiration. For such, it is common for plants to decrease leaf area, both by the reduction in leaf size and by the lower production of leaves. According to Fernández, Mcinnes, and Cotheren (1996), the leaf area is an important factor of production and 
majorly determines photosynthesis rate and water use by plants; its productivity potential is severely inhibited when exposed to water deficit.

Another response to soil compaction occurs in plant root system. Ramos et al. (2018) evaluated soybean roots in areas with no compaction and with low and high compaction levels; according to the authors, three different forms of soil exploration were identified in soybean roots, according to the increasing soil compaction. The first one shows a pivotal behavior (control plants); the second is characterized by shorter primary roots and the presence of numerous secondary roots; and in the third type roots only explore a shallow zone of soil.

On the other hand, the proper development of the root system, especially in depth, promotes greater water capture ability. According to Glinski and Lipiec (2018), when the upper roots are water stressed, plants tend to maintain the transpiration rate by compensatory increase in water uptake from lower unstressed roots.

In this context, this work aimed to evaluate the initial development of shoot and roots of soybean plants, cultivated in different combinations of soil bulk densities and water availability.

\section{Method}

\subsection{Experimental area and design}

The experiment was carried out in a greenhouse at Terras Baixas Experimental Station (ETB), Embrapa Clima Temperado, located in Rio Grande do Sul, Brazil. Soybean plants cv. BMX Ícone were cultivated in PVC pots (15 cm diameter, $25 \mathrm{~cm}$ height), being sowed in October 2017, with seven seeds per pot at a depth of $2 \mathrm{~cm}$. Six days after emergence, thinning was done leaving the four most homogeneous plants.

Experimental design was randomized blocks with four replications in factorial scheme $7 \times 2$. Factor A corresponded to seven levels of soil bulk density $\left(1.4,1.5,1.6,1.7,1.8,1.9\right.$ and $\left.2.0 \mathrm{~kg} \mathrm{dm}^{-3}\right)$ and factor B to two levels of soil water tension (10 and $50 \mathrm{kPa})$.

The procedure to obtain soil bulk density (BD) was to fill the pot with sieved soil in layers of $4 \mathrm{~cm}$, placing in the volume corresponding to that layer the soil mass corresponding to the soil bulk density established, by physical compaction to obtain the correct mass:volume ratio. BD of $1.4 \mathrm{~kg} \mathrm{dm}-{ }^{3}$ corresponded to placing soil in pot without compaction. Soil was collected at ETB experimental field and classified, according to Santos et al. (2018), as Planosol. On field, at $10 \mathrm{~cm}$ depth, natural soil bulk density was $1.6 \mathrm{~kg} \mathrm{dm}^{-3}$.

In each pot, soil water tension (SWT) was monitored by using Watermark ${ }^{\circledR}$ sensors, installed at $0.10 \mathrm{~m}$ depth (vertical sensor center). Watermark ${ }^{\circledR}$ readings were performed every day, early in the morning; when necessary, water was added to restore predefined SWT for the treatment.

\subsection{Measures}

Plants height was measured from the soil surface to the youngest leaf point of insertion once every two days between 1 and 56 days after plant emergence (DAE). From 4 to 56 DAE, leaf area measurements were estimated twice a week by measuring the length and width of the central trifolium of each leaf and multiplying it by a correction factor, according to the method modeled by Richter et al. (2014).

At the end of the experiment (56 DAE), soil penetration resistance (PR) was determined by using an impact penetrometer Stolf type with three measurements per pot. After determination of PR, the soil of each pot was divided in 4 layers for the evaluation of root development, corresponding to depths of $0-5 \mathrm{~cm}, 5-10 \mathrm{~cm}, 10-15$ $\mathrm{cm}$ and $15-20 \mathrm{~cm}$. To separate roots, each soil layer was washed on a $2 \mathrm{~mm}$ sieve. After the separation, the root volume was evaluated by inserting them into a graduated cylinder with water and recording the change in volume, where $1 \mathrm{~mL}$ of water corresponded to $1 \mathrm{~cm} 3$ of roots.

\subsection{Statistics}

To evaluate the relationship between plant height and leaf area with soil bulk density and water tension, the locally weighted regression (LOESS) model was adjusted to each variable (Cleveland \& Devlin, 1988). The effect of soil bulk density and water tension on roots volume was evaluated by comparing regressions based on their respective $95 \%$ confidence intervals $(95 \% \mathrm{CI})$; in sections when they overlapped, there was no difference between regressions; where they did not touch each other, treatments differed. Similarly, for root distribution in soil layers, means were considered distinct when the difference between means was superior to $2 \times$ [95\% CI] (Reinhart, 2015). The soil resistance to penetration as a function of soil depth for different soil bulk densities was evaluated by $1^{\text {st }}$ or $2^{\text {nd }}$ degree linear regressions. All analysis were performed into the $\mathrm{R}$ statistical environment (R Development Core Team, 2016). 


\section{Results and Discussion}

The growth of soybean plants was influenced by increasing soil water tension (Figure 1); from 14 DAE onwards, plants cultivated with adequate water availability $(\mathrm{SWT}=10 \mathrm{kPa})$ were higher than those grown at $50 \mathrm{kPa}$, and this difference was higher as plants aged. At the end of the evaluated period, the height of plants cultivated on water deficit $(\mathrm{SWT}=50 \mathrm{kPa}$ ) was lower in $13 \mathrm{~cm}$, being approximately $30 \%$ lower than those grown under 10 $\mathrm{kPa}$ (Figure 1).

This decrease in plant height under $50 \mathrm{kPa}$ may have occurred due to water and nutrient deficit. Cell growth is the most sensitive process to low water availability in soil (Krame \& Boyer, 1995), and cell division and expansion are directly inhibited by water stress (Zhu, 2002). Nutrient deficiency is also a consequence of lower water availability, since water is the means for nutrients uptake; Al-Kaisi et al. (2013) reports that poor water availability reduced nutrient availability and uptake by plants.

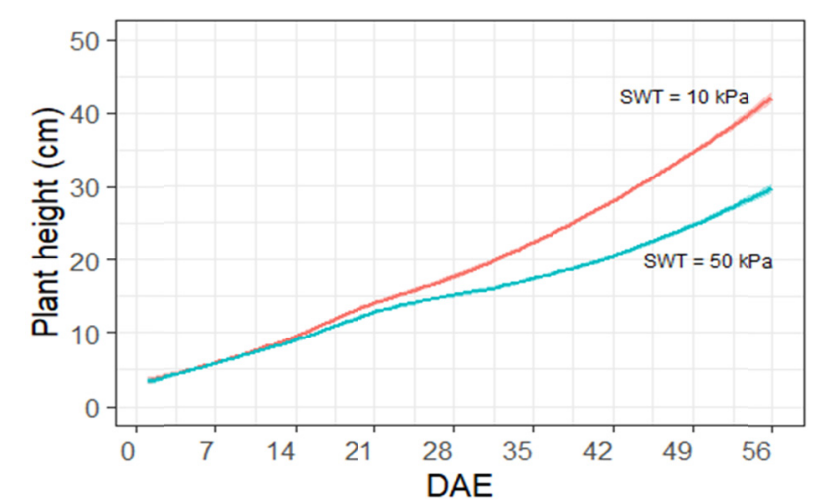

Figure 1. Growth curve of the plant height of soybean cv. BMX Ícone as a function of days after emergence (DAE) cultivated with soil water tension (SWT) of 10 and $50 \mathrm{kPa}$

Besides the effect of soil water tension, increase in soil bulk density also result in plant height modifications (Figure 2). 

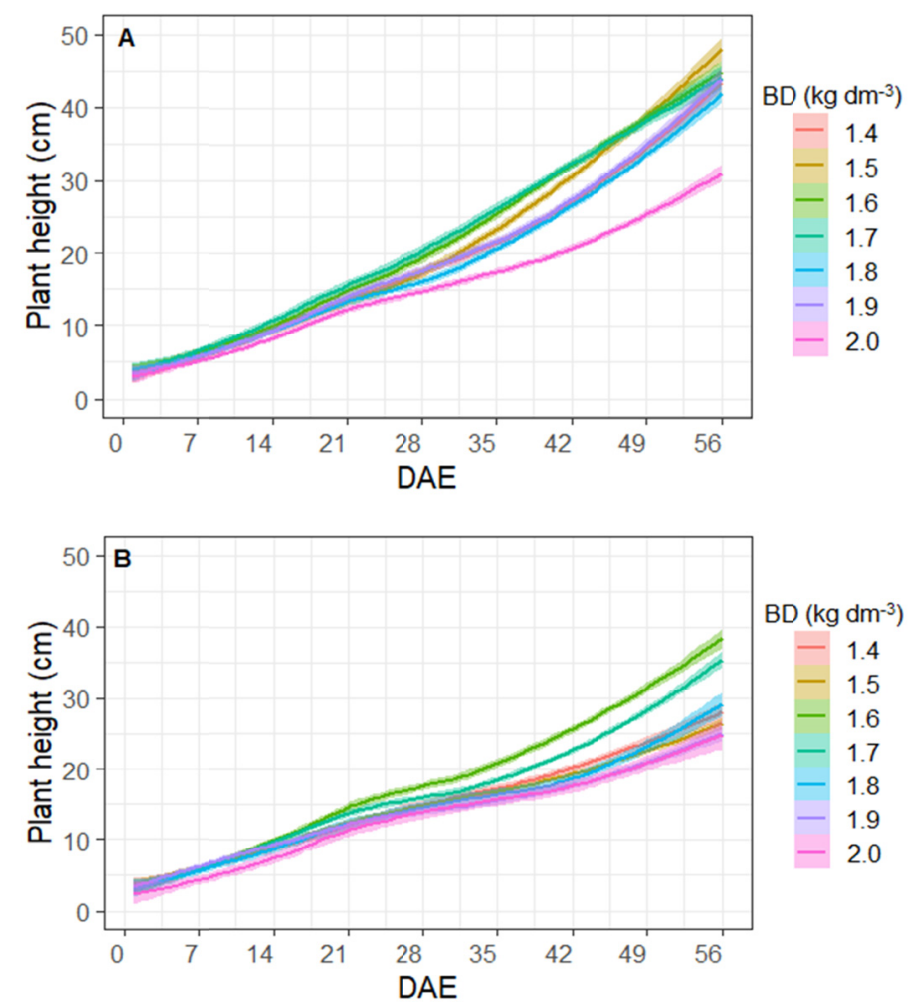

Figure 2. Growth curve of the plant height of soybean cv. BMX Ícone as a function of days after emergence (DAE) for different soil bulk densities (BD) and cultivated with soil water tensions of $10 \mathrm{kPa}(\mathrm{A})$ and $50 \mathrm{kPa}(\mathrm{B})$

In conditions where SWT was $10 \mathrm{kPa}$, only $\mathrm{BD}$ of $2.0 \mathrm{~kg} \mathrm{dm}^{-3}$ had effect on plant height and this is evident from 20 DAE onwards (Figure 2A). Between 30 and 40 DAE, a differential effect of BD between 1.4 and $1.9 \mathrm{~kg} \mathrm{dm}^{-3}$ on plant height was observed, but at the end of the experiment this effect disappears (Figure 2A) and is supposed to be very small or null. At SWT of $50 \mathrm{kPa}$ (Figure 2B), plant height under BD of 1.6 and $1.7 \mathrm{~kg} \mathrm{dm}^{-3}$ were significantly higher compared to the other soil densities, which in turn did not differ from each other (Figure 2B).

Under conditions of lower water availability, BD from $1.8 \mathrm{~kg} \mathrm{dm}^{-3}$ onwards resulted in lower plant height. This may have occurred because the increase in BD results in a decrease in macropores and increase in small pores, which may interfere in both root development and water and nutrient uptake. According to Brady and Weill (1999), roots firstly remove water from the macropores and as these pores are drained, the roots will absorb water from progressively smaller pores in which the matric potential is more negative and the forces of attraction of water to the solid surfaces are most intense. Thus, as the soil dries, it becomes progressively more difficult for plants to remove water from the soil at rates meeting their needs.

The leaf area growth was also influenced by SWT (Figure 3); similarly to the reported for plant height, at the highest soil water tension $(50 \mathrm{kPa})$ the leaf area was significantly lower compared to plants grown in soil with 10 $\mathrm{kPa}$ of water tension. Fioreze et al. (2011) evaluated water deficit effect on soybean genotypes and also observed the lower values of leaf area under conditions of lower water availability. 


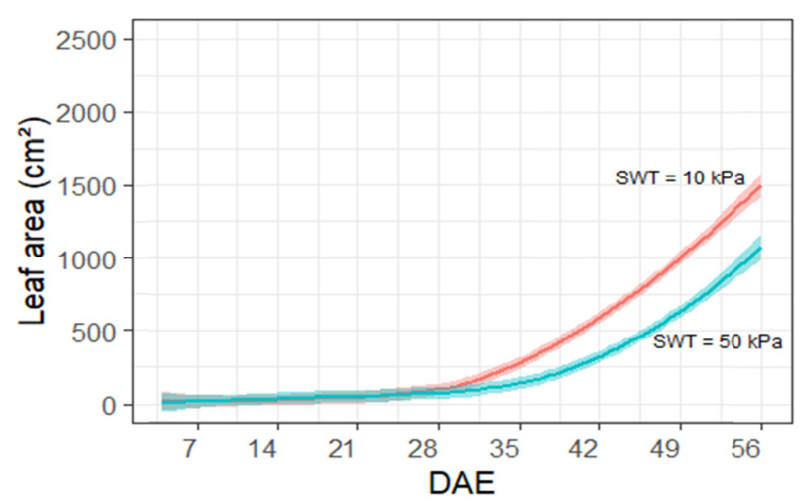

Figure 3. Growth curve of the leaf area of soybean cv. BMX Ícone as a function of days after emergence (DAE) cultivated with soil water tension (SWT) of 10 and $50 \mathrm{kPa}$

The leaf area of plants cultivated under SWT of $10 \mathrm{kPa}$ was lower in BD of $2.0 \mathrm{~kg} \mathrm{dm}^{-3}$ (Figure 4A); the same occurred with plant height (Figure 2A). At this BD level, a reduction in soil hydraulic conductivity may have occurred, and roots may have found physical impediment to its development, and consequently the water demand of plants, was not properly supplied. Plant water demand depends on transpiration, which varies greatly according to climatic conditions, root density and its efficiency in absorbing water, which depends on the hydraulic conductivity of both roots and soil (Kramer \& Boyer, 1995).

When SWT was $50 \mathrm{kPa}$ (Figure 4B) highest leaf area values, as well as plant height, occurred on BD of 1.6 and $1.7\left(\mathrm{~kg} \mathrm{dm}^{-3}\right)$. This may have occurred in the most compacted treatments because increased soil bulk density (increased microporosity and water retention strength in the soil) made difficult for roots to absorb water, further increasing the water deficit and limiting leaf expansion. For treatments with low-density soils, the predominance of macropores allowed soybean plants to excessively lose water by luxury consumption, and plants did not have enough water when they really needed it (Parfitt et al., 2017). According to Santos and Carlesso (1998), in situations of water deficit, there may be either a reduction in the size of individual leaves or a smaller production of leaves. Since the leaf area determines plant water use, Fageria (1989) cites the decrease of leaf area as an alternative to reduce water loss through transpiration. This, unfortunately, can also limit photosynthesis rate (Gurevitch, Scheiner, \& Fox, 2009). 

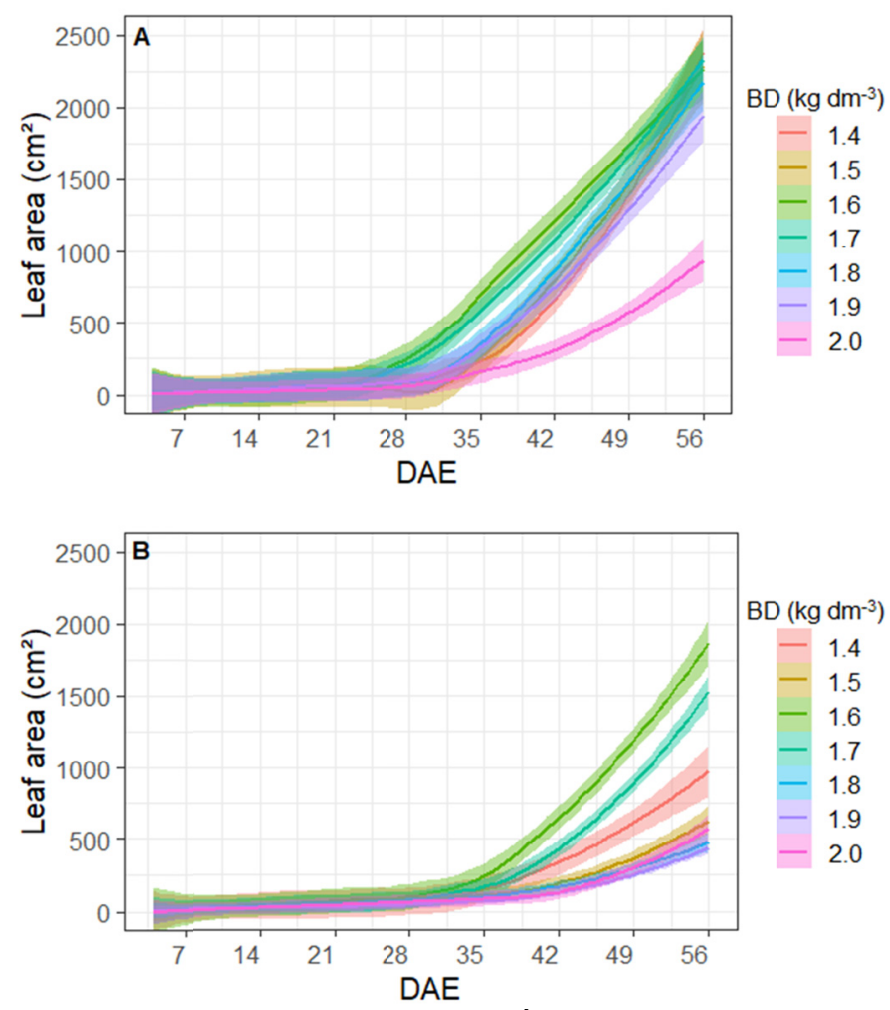

Figure 4. Growth curve of the leaf area of soybean cv. BMX Ícone as a function of days after emergence (DAE) for different soil bulk densities (BD) and cultivated with soil water tensions of $10 \mathrm{kPa}(\mathrm{A})$ and $50 \mathrm{kPa}(\mathrm{B})$

Figure 5 shows the distribution of soybean root volumes at different depths under different soil bulk densities and water tensions. In BD of 1.5 and $1.6 \mathrm{~kg} \mathrm{dm}^{-3}$ and SWT of $10 \mathrm{kPa}$ there was a higher total volume of roots and a more homogeneous distribution along the $20 \mathrm{~cm}$ of soil depth in the experimental units. With the BD increase, the highest root volume was concentrated in the $0-5 \mathrm{~cm}$ layer, reaching $82 \%$ of the roots developing only at that depth under BD $2.0 \mathrm{~kg} \mathrm{dm}^{-3}$. These results are according to those of Valadão et al. (2015) who assessed the distribution of soybean roots in soil as a function of the number of tractor passes, reporting that under higher compaction, $75 \%$ of the roots were concentrated at the $0-5 \mathrm{~cm}$ layer. 

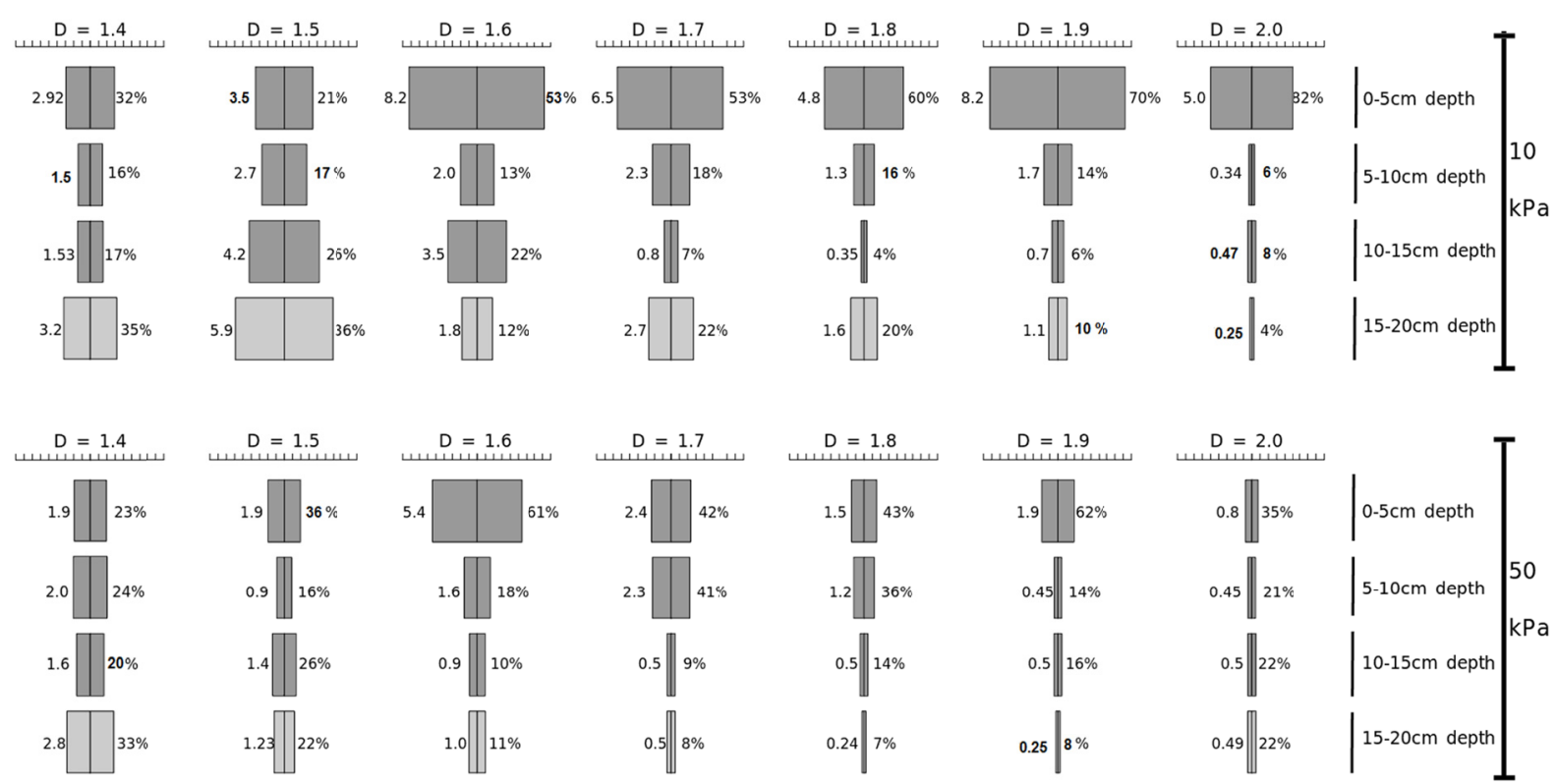

Figure 5. Mean values of roots volume $\left(\mathrm{cm}^{3} \mathrm{dm}^{-3}\right.$ of soil) of soybean plants cv. BMX Ícone in different soil bulk densities $\left(\mathrm{D}=1.4-2.0 \mathrm{~g} \mathrm{~cm}^{-3}\right)$, soil water tension $(10$ and $50 \mathrm{kPa})$, and soil layers $(0-5 \mathrm{~cm}, 5-10 \mathrm{~cm}, 10-15 \mathrm{~cm}$,

$15-20 \mathrm{~cm}$ depth). Confidence interval (95\%): $0.5 \mathrm{~cm}^{3} \mathrm{dm}^{-3}$

The higher root concentration in shallow soil layers can occur because under soil compaction, the growth of lateral roots occurs from the main root, and not from the secondary ones, and the greater number of lateral roots is in the zone near the base of the stem (Ramos et al., 2018).

In soil water tension of $50 \mathrm{kPa}$ associated to soil density up to $1.5 \mathrm{~kg} \mathrm{dm}^{-3}$, the root distribution along soil layers was similar to the SWT of $10 \mathrm{kPa}$ (Figure 5). However, the total volume of roots in the treatment of $10 \mathrm{kPa}$ was higher in all soil bulk densities, evidencing the limitation of plant development in conditions of lower water availability. According to Raven, Evert \& Ichrorn (1996), water loss reduces the cellular turgor, therefore it is believed that turgor-dependent activities as rooting are also limited by water deficit, and this is highly evidenced by our data.

Figure 6 shows the soil penetration resistance (PR) data for the different soil bulk densities. With BD of 1.4 and $1.5\left(\mathrm{~kg} \mathrm{dm}^{-3}\right)$ the PR values were close to $0.0 \mathrm{MPa}$ and did not vary in depth. From the BD of $1.6 \mathrm{~kg} \mathrm{dm}^{-3}$ onwards, the PR increases significantly, especially between 5 and $15 \mathrm{~cm}$ depth. Although the initial BD was the same for the entire pot, with both root growth and water movement, the soil particles were rearranged, especially at depth. 


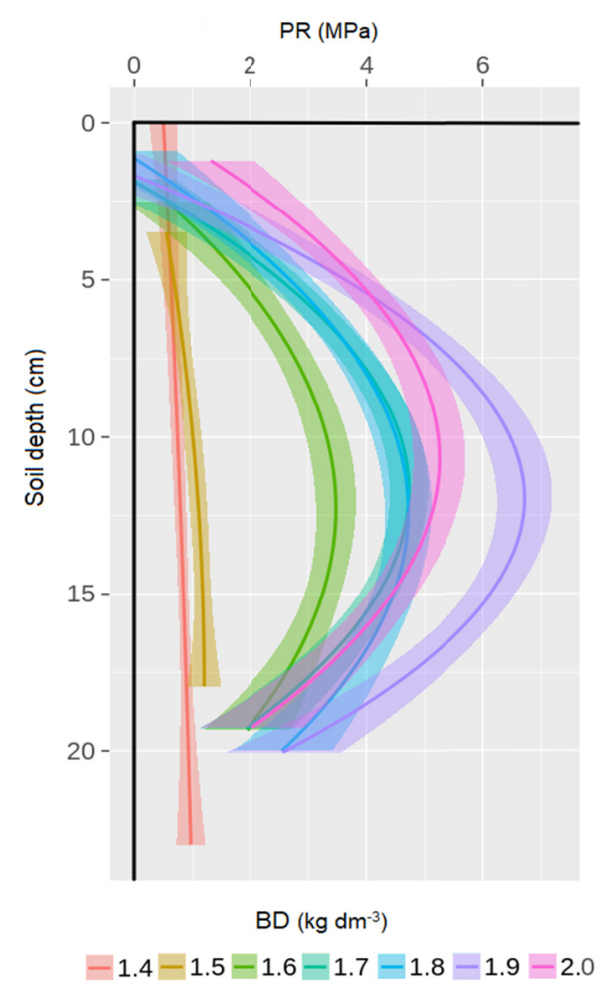

Figure 6. Soil penetration resistance (PR) at different soil bulk densities (BD) cultivated with soybean cv. BMX Ícone. $1^{\text {st }}$ and $2^{\text {nd }}$ degree linear regressions, respectively for $1.4-1.5 \mathrm{~kg} \mathrm{dm}^{-3}$; and $1.6-2.0 \mathrm{~kg} \mathrm{dm}^{-3}$. All equations were significant at $5 \%$ probability with $\mathrm{r}^{2}$ superior to $80 \%$

At the $0-5 \mathrm{~cm}$ soil layer, from BD of $1.6 \mathrm{~kg} \mathrm{dm}^{-3}$ onwards, the lowest PR values were found (Figure 6), as well as the highest roots volume (Figure 5) for all soil bulk densities. These results confirm those of Beutler and Centurion (2004) which evaluated the effect of soil compaction on root development and soybean yield and concluded that increased soil compaction increases root density in the 0-0.05 m layer. According to Colombi and Water (2015), soil compaction caused soybean roots to grow shallower and penetrate the soil less deep.

The results from the current study suggest that treatment differences in soybean growth were mainly caused by differences in water availability. In general the height, leaf area and root volume of plants were lower in the SWT $=50 \mathrm{kPa}$ even in the smaller soil bulk densities, and when the SWT was $10 \mathrm{kPa}$ only in the soil bulk density of $2.0 \mathrm{~kg} \mathrm{dm}^{-3}$ plant growth was lower. According to Colombi, Torres, Walter, and Keller (2018), interactive effects between soil penetration resistance, root architecture and plant water uptake determine water accessibility by roots and ultimately affect crop growth. Root growth became shallower in response to increased top soil penetration resistance, which increased water uptake from the topsoil. In return, this led to further increased topsoil penetration resistance. As a consequence of this feedback, root growth into deeper soil layers and thus water uptake from the subsoil was restricted, which decreased plant growth and crop productivity.

\section{Conclusions}

Plant height and leaf area, as well as root volume, decreased when soybean was cultivated at $50 \mathrm{kPa}$, associated to soil bulk densities above $1.8 \mathrm{~kg} \mathrm{dm}^{-3}$.

Soybean crop showed to be most sensitive to water deficit than to soil compaction. Thus, for the adequate development of soybean, a crop management based in keeping soil water tension around the field capacity (10 $\mathrm{kPa}$ ) and the soil bulk density lower than $1.8 \mathrm{~kg} \mathrm{dm}^{-3}$ should be adopted. Field-level studies should be installed to support this evidence.

\section{References}

Al-Kaisi, M. M., Elmore, R. W., Guzman, J. G., Hanna, H. M., Hart, C. E., Helmers, M. J., ... Sawyer, J. E. (2013). Drought impact on crop production and the soil environment: 2012 experiences from Iowa. Journal of Soil and Water Conservation, 68(1), 19-24. https://doi.org/10.2489/jswc.68.1.19A 
Beulter, A. N., \& Centurion, J. F. (2004). Compactação do solo no desenvolvimento radicular e na produtividade da soja. Pesquisa Agropecuária Brasileira, 39(6), 581-588. https://doi.org/10.1590/S0100-204X2004000 600010

Beulter, A. N., \& Centurion, J. F. (2003). Efeito do conteúdo de água e da compactação do solo na produção de soja. Pesquisa Agropecuária Brasileira, 38(7), 849-856. https://doi.org/10.1590/S0100-204X2003000 700009

Brady, N. C., \& Weil, R. R. (1999). Elements of the Nature and Properties of Soils. New Jersey: P. Hall.

Calonego, J. C., Raphael, J. P. A., Rigon, J. P. G., Oliveira Neto, L., \& Rosolem, C. A. (2017). Soil compaction management and soybean yields with cover cropsunder no-till and occasional chiseling. European Journal of Agronomy, 85, 31-37. https://doi.org/10.1016/j.eja.2017.02.001

Cardoso, E. G., Zotarelli, L., Piccinin, J. L., Torres, E., Saraiva, O. F., \& Guimarães, M. F. (2006). Sistema radicular da soja em função da compactação do solo no sistema plantio direto. Pesquisa Agropecuária Brasileira, 41(3), 493-501. https://doi.org/10.1590/S0100-204X2006000300017

Chen, G., Weil, R. R., \& Hill, R. L. (2014). Effects of compaction and cover crops on soilleast limiting water range and air permeability. Soil and Tillage Research, 136, 61-69. https://doi.org/10.1016/j.still.2013.09.004

Cleveland, W. S., \& Devlin, S. J. (1988). Locally Weighted Regression: An Approach to Regression Analysis by Local Fitting. Journal of the American Statistical Association, 83(403), 596-610. https://doi.org/10.2307/ 2289282

Colombi, T., \& Walter, A. (2016). Root responses of triticale and soybean to soil compaction in the field are reproducible under controlled conditions. Functional Plant Biology, 43(2), 114-28. https://doi.org/10.1071/ FP15194

Colombi, T., Torres, L. C., Walter, A., \& Keller, T. (2018). Feedbacks between soil penetration resistance, root architecture and water uptake limit water accessibility and crop growth: a vicious circle. Science of the Total Environment, 626, 1026-1035. https://doi.org/10.1016/j.scitotenv.2018.01.129

Fageria, N. K. (1989). Solos tropicais e aspectos fisiológicos das culturas. Brasília, DF: EMBRAPA-DPU: EMBRAPA-CNPAF.

Fernández, C. J., Mcinnes, K. J., \& Cothren, J. T. (1996). Water status and leaf area production in water-and nitrogen-stressed cotton. Crop Science, 36(5), 1224-1233. https://doi.org/10.2135/cropsci1996.0011183X 003600050026x

Fioreze, S. L., Pivetta, L. G., Fano, A., Machado, F. R., \& Guimarães, V. F. (2011). Performance of soybean genotypes under high intensity drought stress in greenhouse conditions. Revista Ceres, 58(3), $342-349$. https://doi.org/10.1590/S0034-737X2011000300015

Gliñski, J., \& Lipiec, J. (1990). Soil physical conditions and plant roots. Boca Raton: CRC Press.

Gurevitch, J., Scheiner, S. M., \& Fox, G. A. (2009). Plant ecology. Porto Alegre: Artmed.

Jones, H. G. (1992). Plants and microclimate: a quantitative approach to environmental plant physiology (2nd ed.). Cambridge: Cambridge University Press.

Kramer, P. J., \& Boyer, J. S. (1995). Water relations of plants and soils. San Diego: Academic press.

Parfitt, J. M. B., Concenço, G., Downing, K., Larue, J. L., \& Silva, J. T. (2017). Rice growth under water stress levels imposed at distinct developmental stages. Revista de Ciências Agrárias, 40, 587-596. https://doi.org/ 10.19084/RCA16133

R Development Core Team. (2016). R: A language and environment for statistical computing. Vienna: R Foundation for Statistical Computing. Retrieved from https:/www.R-project.org

Ramos, J. C., Céccoli, G., Panigo, E. S., Dellaferrera, I. M., Moras, G., Vegetti, A. C., \& Perreta, M. G. (2018). Novel topological-architectural parameters of root growth in soybean (Glycine max (L.) Merrill) to determine the presence of soil mechanical impedance. Indian Journal of Science and Technology, 11(3), 1-13. https://doi.org/10.17485/ijst/2018/v11i3/108620

Raven, H. P., Evert, R. F., \& Eichhorn, S. E. (1996). Biologia Vegetal (5th ed.). Rio de Janeiro: Guanabara Koogan.

Reinhart, A. (2015). Statistics done wrong. San Francisco: No Start Press. 
Richter, G. L., Zanon Jr., A., Streck, N. A., Guedes, J. V. C., Kraulich, B., Rocha, T. S. M., ... Cera, J. C. (2014). Estimativa da área de folhas de cultivares antigas e modernas de soja por método não destrutivo. Bragantia, 73(4), 416-425. https://doi.org/10.1590/1678-4499.0179

Santos, H. G., Jacomine, P. K. T., Anjos, L. H. C., Oliveira, V. A., Lumbreras, J. F., Coelho, M. R., ... Cunha, T. J. F. (2018). Sistema brasileiro de classificação de solos (5th ed.) Brasília: Embrapa.

Santos, R. F., \& Carlesso, R. (1998). Déficit hídrico e os processos morfológico e fisiológico das plantas. Revista Brasileira de Engenharia Agrícola e Ambiental, 2(3), 287-294. https://doi.org/10.1590/1807-1929/agriambi

Sartori, G. M. S., Marchesan, E., David, R. D., Nicoloso, F. T., Schorr, M. R. W., \& Donato, G. (2016). Growth and development of soybean roots according to planting management systems and irrigation in lowland areas. Ciência Rural, 46(9), 1572-1578. https://doi.org/10.1590/0103-8478cr20151579

Valadão, F. C. A., Weber, O. L. S., Valadão Júnior, D. D., Scapinelli, A., Deina, F. R., \& Bianchini, A. (2015). Adubação fosfatada e compactação do solo: Sistema radicular da soja e do milho e atributos físicos do solo. Revista Brasileira de Ciência do Solo, 39, 243-255. https://doi.org/10.1590/01000683rbcs20150144

Watson, G. W., \& Kelsey, P. (2006). The impact of soil compaction on soil aeration and fine root density of Quercus palustris. Urban Forestry \& Urban Greening, 4, 69-74. https://doi.org/10.1016/j.ufug.2005.08.001

Zhu, J. K. (2002). Salt and drought stress signal transduction in plants. Annual Review of Plant Biology, 53, 247-273. https://doi.org/10.1146/annurev.arplant.53.091401.143329

\section{Copyrights}

Copyright for this article is retained by the author(s), with first publication rights granted to the journal.

This is an open-access article distributed under the terms and conditions of the Creative Commons Attribution license (http://creativecommons.org/licenses/by/4.0/). 